\title{
RELATION BETWEEN EXTENSIVE EXTREME PRECIPITATION IN POLAND AND ATMOSPHERIC CIRCULATION
}

\author{
Jakub Nowosad, Alfred Stach \\ Institute of Geoecology and Geoinformation, Adam Mickiewicz University in Poznań, Poland
}

Manuscript received: January 07, 2014

Revised version: February 14, 2014

\begin{abstract}
Nowosad J., STACH A., 2014. Relation between extensive extreme precipitation and atmospheric circulation. Quaestiones Geographicae 33(1), Bogucki Wydawnictwo Naukowe, Poznań, pp. 115-129, 10 figs, 5 tables. DOI 10.2478/ quageo-2014-0005, ISSN 0137-477X

ABSTRACT: The basic aim of this study was to find relations between the dates of occurrence and characteristics of extensive extreme daily (24-h) precipitation totals (EEDPTs) and pressure systems. The analysis was conducted on the basis of precipitation data from the multi-year period 1956-1980 and the Grosswetterlagen classification of circulation situations. EEDPTs were taken to embrace those cases of maximum annual daily precipitation totals that were registered on the same day at a minimum of 75 precipitation stations. In the years 1956-1980 there were 209 such events. The hypothesis about the effect of a circulation situation on the probability of occurrence of an EEDPT was verified in quantitative terms, the reference being both the entire multi-year period and the seasonal variation in the occurrence of precipitation of this type. Next, circulation situations were compared in terms of amount-related parameters of EEDPTs (mean precipitation, coefficient of variation), their spatial features (perimeter, area), and precipitation volume. The analyses performed show a statistically significant dependence between the atmospheric circulation and extensive extreme precipitation. It was demonstrated that there were circulation situations during which EEDPTs occurred much more often or much more rarely than over the entire multi-year period under study. Also identified was the connection of an atmospheric circulation with the mean amount, coefficient of variation and volume of extensive extreme precipitation.

KEY WORDS: extensive extreme precipitation, daily precipitation totals, atmospheric circulation, Grosswetterlagen, Poland Address of the corresponding author: Jakub Nowosad, Institute of Geoecology and Geoinformation, Adam Mickiewicz University in Poznań, Dzięgielowa 27, 61-680 Poznań, Poland, e-mail: nowosad@amu.edu.pl
\end{abstract}

\section{Introduction}

Extreme precipitation is the main cause of floods. They often bring about both, disturbances in the environmental equilibrium and economic losses, and sometimes also a loss of life. That is why research on the genesis and quantitative characteristics of this type of events is of great significance (Heino et al. 1999). The possibility of forecasting them, if only as a probability, would give people a chance of avoiding much damage. High daily precipitation totals mostly produce rises and floods in small catchments and in urbanised areas. However, if there is an extreme rainfall over a large area or for many days, the effect can be a most catastrophic flood. An example of such a situation in Poland was the so-called 'millennium flood' of July 1997, which caused losses in excess of 9 billion zlotys (International Commission for the Protection of the Odra River against Pollution 1999) and a death toll of 54. Other, similar cases were noted in July 1934, July 1970 (Niedźwiedź et al. 1999), and May and June 2010.

The issue of atmospheric precipitation in normal and anomalous amounts has been taken 
up in the Polish climatological literature many times (Mrugała 2001). In the recent years, one of the scholars dealing with it has been Twardosz (2009). He examined the relation between three precipitation characteristics in Cracow: maximum amount, duration, and the so-called above-threshold probability. An effect of his work was a probabilistic model describing dependencies among those characteristics. In turn, Łupikasza (2010b, Łupikasza et al. 2011) sought tendencies in the temporal and spatial variability of extreme precipitation. She found a downward trend in the occurrence of days with high daily precipitation totals in Poland over the years 1951-2006.

There have also been many publications reporting a search for a connection between atmospheric circulation and atmospheric precipitation. Most of them focused on the influence of circulation on precipitation in mountain areas and the disastrous effects of high rainfall totals (Morawska-Horawska 1971, Kwiatkowski 1984, Cebulak 1992 after Ustrnul, Czekierda 2001). As a consequence, we have a fairly good knowledge of circulation situations responsible for high precipitation values in mountain areas. It has been found that the chief factors here are a relatively weak cyclonic system over south-eastern Poland, Hungary or western Ukraine bringing cold and moist air masses from the north and north-west, as well as mountains as an orographic barrier causing the condensation of water vapour (Ustrnul, Czekierda 2001).

However, there have been relatively few analyses embracing the entire area of Poland, and often based on short measurement series or only monthly precipitation totals (Kożuchowski 1986, Bogucka 1998 after Ustrnul, Czekierda 2001). Relying on an almost 50-year measurement series and data from 53 Polish measuring stations, Ustrnul and Czekierda (2001) took up this problem using the Grosswetterlagen classification. Their research confirmed that atmospheric circulation could bring extreme values of precipitation, the main cause of their occurrence being the inflow of air masses from the north, north-west, or west. They also found that what controlled maximum daily precipitation totals was a cyclonic system of winds over Central Europe. Twardosz (2007) sought to establish day-to-day variations in the frequency of atmospheric precipitation in the warm half of the year with reference to circulation types in Cracow using their classification proposed by Niedźwiedź. Łupikasza (2010a) undertook to describe and compare the circulation classifications proposed by Lityński, Niedźwiedź and Ustrnul, and to analyse them in terms of the probability of high values (in excess of $10 \mathrm{~mm}$ ) of daily precipitation totals. She also confirmed that cyclonic wind systems played a significant role in producing high rainfall.

The research on extreme precipitation over the area of Poland largely focuses on the temporal and spatial variations in precipitation and its connection with atmospheric circulation. However, those studies are not flawless, in particular because of scholars relying on too small a number of measuring stations and tending to concentrate on temporal variations. They have not taken up issues concerning extensive extreme daily precipitation totals, their amount or spatial features, basing their conclusions on a study of a large population of this type of events selected according to a uniform criterion. Since the greatest threat is posed by high and lasting precipitation over extensive areas, the spatial criterion of identifying extremes should be as important as that of the amount or recurrence of precipitation.

The chief aim of this article is to establish relations between atmospheric circulation and extensive extreme precipitation in Poland. A study was made of the frequency of its occurrence in the individual circulation types and the potential role of its seasonal variations. Next, using the precipitation totals obtained and their location, a relation was sought between the individual circulation situations and the mean value of precipitation, its volume, the size of the area where an extensive extreme daily precipitation total (EEDPT) occurred, and its perimeter. To this end use was made of the Grosswetterlagen typology (GWL) (Gerstengarbe et al. 1999). It is useful for analyses of a connection between atmospheric pressure and other climatic characteristics of Central Europe. Based on near-surface pressure patterns and those at an altitude of $500 \mathrm{hPa}$, it is especially helpful in precipitation studies (Ustrnul, Czekierda 2001). Earlier research employing data from the area of Poland has corroborated GWL to be of great value (Ustrnul, Czekierda 2001, Nowosad 
2007, Radomski 2008, Radomski, Widawski 2011, Ustrnul, Wypych 2011).

\section{Measurement data}

The analyses presented below rely on data embracing daily atmospheric precipitation totals and circulation types.

The basic source of information about precipitation amounts was Precipitation Yearbooks embracing the years 1956-1980, published by the State Hydro-Meteorological Institute and then by the Institute of Meteorology and Water Management. They contain, among other data, maximum annual daily precipitation totals from all measuring stations and daily precipitation totals from about 350 measuring sites. The above study period is especially important because of the relatively high density of the measuring network: the number of rainfall stations ranged from 1,867 in 1956 to 2,654 in 1975 (Stach 2009). Today the Polish measuring network is half this size (Stachy 1999). The database thus obtained was then expanded to include analogous data collected by the German Meteorological Service (Deutscher Wetterdienst) in a $30-\mathrm{km}$ wide zone west of the Polish border. The database contained planar rectangular coordinates of the rainfall stations in the 1992 system (PUWG 1992), their altitude in metres above sea-level, and a daily precipitation total in millimetres.

With the above data set at hand, an arbitrary assumption was made that extensive extreme daily precipitation totals (EEDPTs) were situations when a maximum annual daily precipitation total was recorded one day at a minimum of 75 measuring stations. This number of data allows calculating reliable statistics, both classical and spatial. On the other hand, taking into consideration the multi-year average density of measurement sites and assuming precipitation continuity, this means that the precipitation area has to cover at least 10 thous. $\mathrm{km}^{2}$. Such a situation occurred 209 times over the 1956-1980 period.

A maximum annual daily precipitation total on the 209 dates examined was recorded 34,321 times. Those data were augmented with a set of 80,074 daily precipitation totals available from the Precipitation Yearbooks (ca. 350 stations each year). Thus, initially our database contained 114,395 measurements of daily precipitation totals, but some of the data repeated themselves. Some daily totals were published both, as a maximum annual 24-h total and as a daily-measured 24-h total. It was necessary to identify those cases and to remove the duplicates. As a result, the ultimate database had 109,123 entries concerning the locations and values of daily precipitation totals.

The rate of the kernel density of the EEDPT data to all the maximum annual daily totals from the 209 dates showed significant spatial variations in the frequency and value of the extensive extreme precipitation. It usually occurs, and is the most efficient, in the West Carpathians, the Sudeten, between the mid-course of the Vistula and Warta, and in the mid-course of the Oder (Fig. 1). The spatial distribution of EEDPTs also displays seasonal variations. The EEDPT dates examined show a strong seasonal variability, too: $86 \%$ of the recorded cases can be found between the last decade of May and the last decade of August. The earliest case of an EEDPT was noted on 2 April, and the last one, on 22 November (Fig. 2). The EEDPTs recorded in April and between September and November are markedly less efficient than in the remaining months.

The EEDPT dates were compared against circulation types registered in the German Grosswetterlagen classification (GWL) (Table 1). It has been worked out by Hess and Berezowsky (Gerstengarbe et al. 1999) on the basis of the earlier works by Baur (James 2006). Today it is made available and kept up-to-date by the German Meteorological Service, and it is possible to obtain data for a period from 1881 to 2012. The procedure of determining GWL circulation situations involves identifying the direction of movement of air masses, the location of pressure centres, and the type of rotation - cyclonic or anticyclonic (Schubert 1994). The direction of air masses defines one of the three types of circulation - zonal, meridional or mixed. Next, depending on the location of a high, a low, and a frontal zone, one of eighteen weather situations is distinguished within them. The last stage is the identification of the wind system - cyclonic or anticyclonic, taking into consideration the pattern of isobars over Central Europe (Gerstengarbe et al. 1999). To determine one of the twenty nine GWL categories, a 


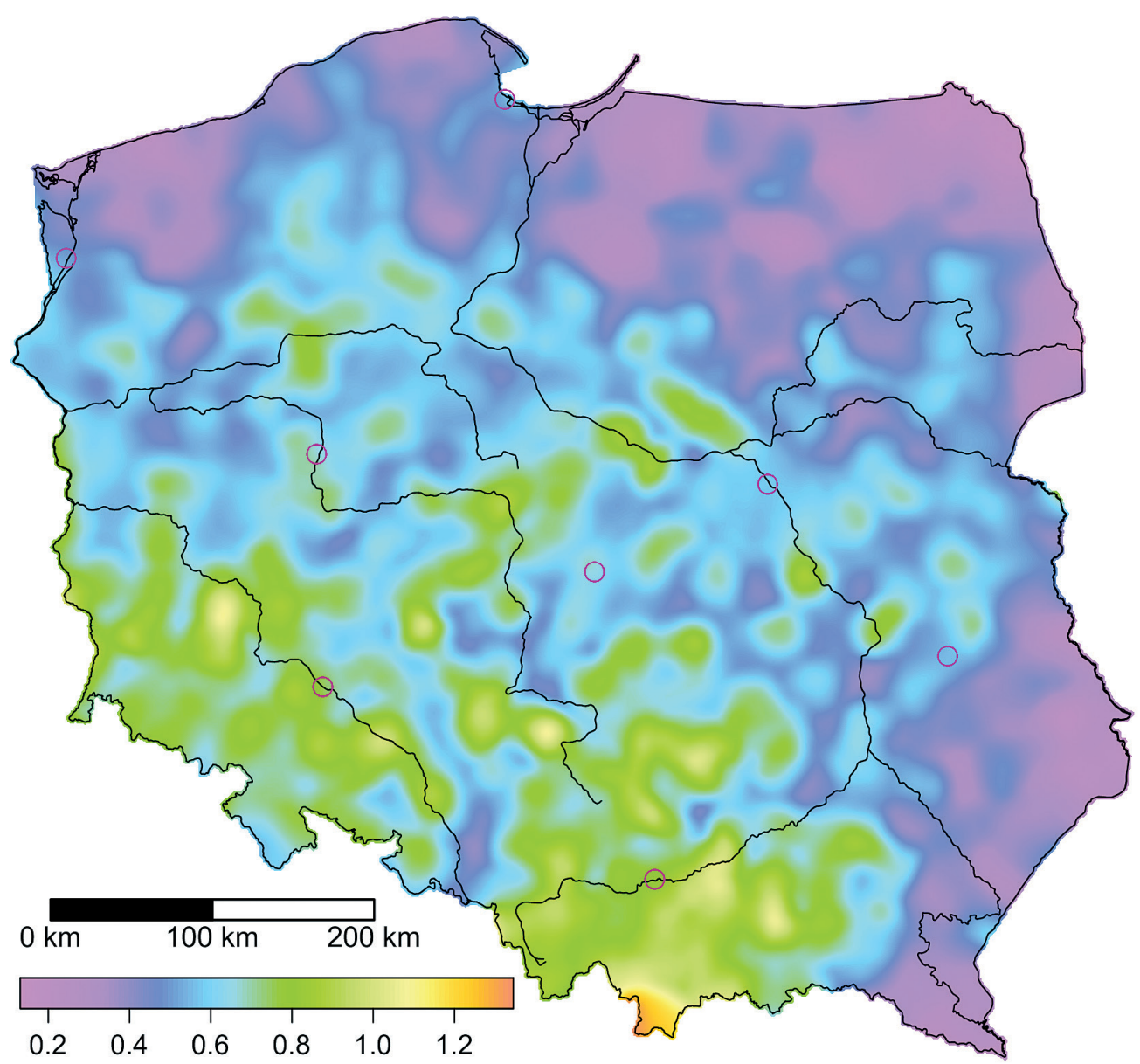

Fig. 1. Rate of the frequency and value of extensive extreme daily precipitation totals (EEDPTs) to the distribution of all maximum annual daily precipitation totals from the 1956-1980 period determined on the basis of kernel density estimation

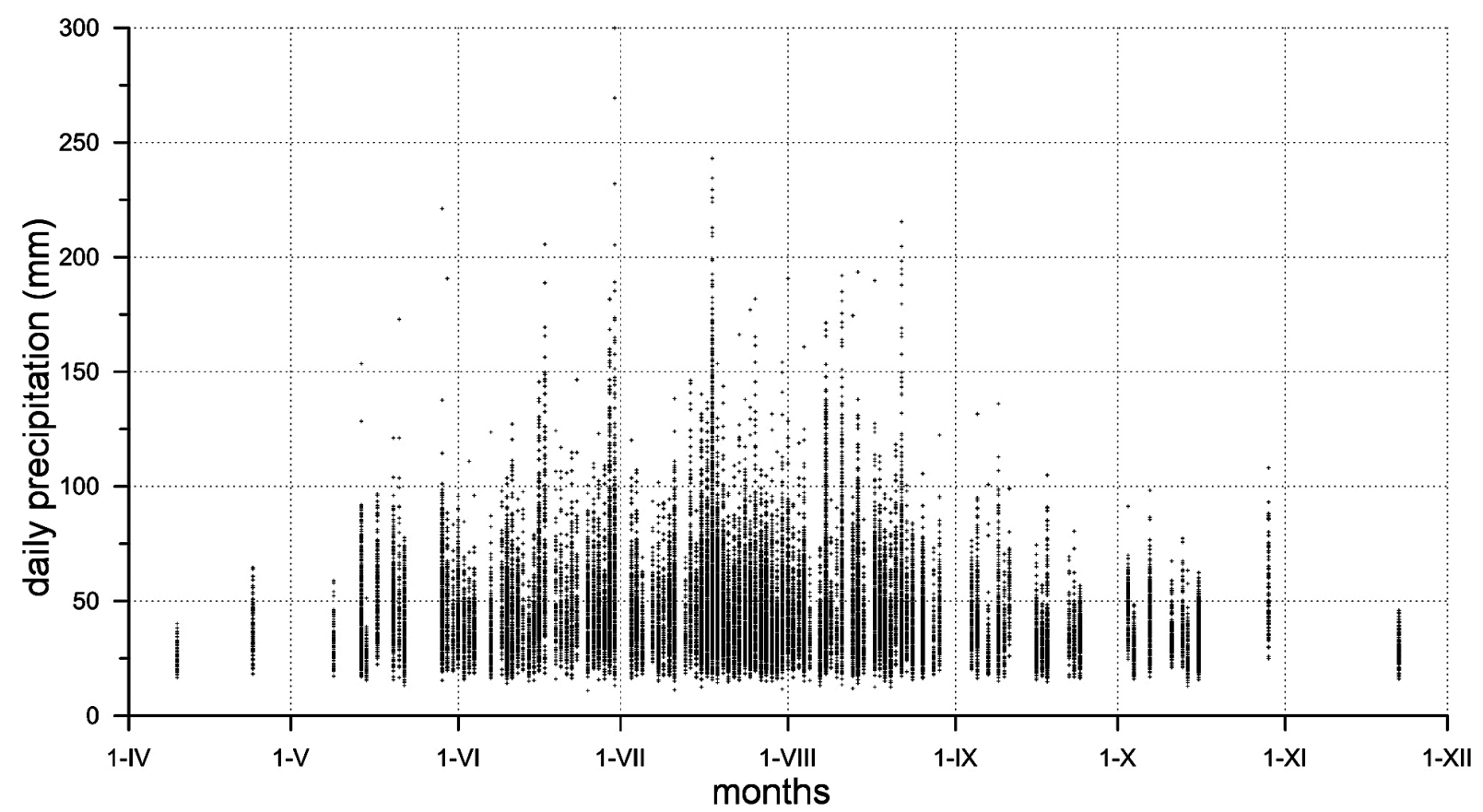

Fig. 2. Distribution over the year of the selected 209 cases of extensive maximum annual daily precipitation totals registered in the 1956-1980 period (ignoring the 'usual' daily totals for the same dates) 
Table 1. List of Grosswetterlagen circulation situations (Gerstengarbe et al. 1999)

\begin{tabular}{|c|c|c|}
\hline No. & Name & Abbr. \\
\hline \multicolumn{3}{|c|}{ ZONAL GROUP } \\
\hline 1 & West, anticyclonic & WA \\
\hline 2 & West, cyclonic & WZ \\
\hline 3 & Southern west & WS \\
\hline 4 & Angleformed west & WW \\
\hline \multicolumn{3}{|c|}{ MIXED GROUP } \\
\hline 5 & South-west, anticyclonic & SWA \\
\hline 6 & South-west, cyclonic & SWZ \\
\hline 7 & North-west, anticyclonic & NWA \\
\hline 8 & North-west, cyclonic & NWZ \\
\hline 9 & Central European high & $\mathrm{HM}$ \\
\hline 10 & Central European ridge & BM \\
\hline 11 & Central European low & TM \\
\hline \multicolumn{3}{|c|}{ MERIDIONAL GROUP } \\
\hline 12 & North, anticyclonic & NA \\
\hline 13 & North, cyclonic & NZ \\
\hline 14 & North, Iceland high, anticyclonic & HNA \\
\hline 15 & North Iceland high, cyclonic & HNZ \\
\hline 16 & British Isles high & HB \\
\hline 17 & Central European trough & TRM \\
\hline 18 & North-east, anticyclonic & NEA \\
\hline 19 & North-east, cyclonic & NEZ \\
\hline 20 & Fennoscandian high, anticyclonic & HFA \\
\hline 21 & Fennoscandian high, cyclonic & HFZ \\
\hline 22 & $\begin{array}{l}\text { Norwegian Sea-Fennoscandian } \\
\text { high, anticyclonic }\end{array}$ & HNFA \\
\hline 23 & $\begin{array}{l}\text { Norwegian Sea-Fennoscandian } \\
\text { high, cyclonic }\end{array}$ & HNFZ \\
\hline 24 & South-east, anticyclonic & SEA \\
\hline 25 & South-east, cyclonic & SEZ \\
\hline 26 & South, anticyclonic & SA \\
\hline 27 & South, cyclonic & SZ \\
\hline 28 & British Isles low & TB \\
\hline 29 & Western European trough & TRW \\
\hline 30 & Unclassified & $\mathrm{U}$ \\
\hline
\end{tabular}

minimum of a three-day characteristic system of air-mass flow (the so-called regime) is needed. If this condition is not met, the given date is defined as unclassified - U (Gerstengarbe et al. 1999).

\section{Methods}

The analysed days of extensive extreme daily precipitation were selected on the basis of the number of measuring stations that registered a maximum annual daily precipitation total on the given day. The minimum number of stations assumed arbitrarily was 75; in the future this will allow a geostatistical analysis of the spatial structure of EEDPTs taking anisotropy into account (Isaaks, Srivastava 1989, Leuangthong et al. 2004). Over the 25-year period under study, such a situation occurred 209 times. For each of the selected dates a database was created consisting of maximum annual daily precipitation totals combined with daily precipitation totals measured for each day of the year.

Using the data collected for each date, a kernel density estimation was made (Levine 2010). It is one of the possible interpolation techniques employed to generalise point phenomena over the entire study area. The procedure consists in placing a symmetric area over each point and determining the distance from the point to the given site on the basis of mathematical functions. It is reiterated at each location examined. The last stage is the summation of values for all sites at each place of the study area (Levine 2010). The above technique requires a choice of several parameters that can affect the result obtained, i.e. an interpolation grid, a distribution density function, and the bandwidth. The interpolation grid employed in this article was one with a $4-\mathrm{km}^{2}$ cell area. This resolution turned out to be sufficiently precise while not prolonging the calculation time unduly. The normal distribution function was chosen as the most useful, because it was the only one that allowed extrapolating kernel density. A variable bandwidth was defined based on the adopted minimum of 25 possible points available. This made it possible to maintain a steady statistical precision of the results. Additionally an atmospheric precipitation total was adopted as a weight value, thus emphasising the significance of a location with high daily precipitation totals.

Using a histogram, the place was determined where a clear drop in the size of kernel density classes could be observed (Fig. 3B). In this way threshold values were established for the identification of areas with the highest kernel density 
values for each of the dates. On their basis the kernel density map was reclassified (Fig. 3C). Areas with especially dense points of high precipitation totals were assigned the code ' 11 ' and converted into polygons (Fig. 3D). The areas obtained in this way were enlarged to include a buffer zone of 50-kilometre width in order to facilitate the determination of the spatial extent of precipitation, and as a consequence, the autocorrelation range (Fig. 3E). The last stage of data preparation was a selection of point data, i.e. locations, together

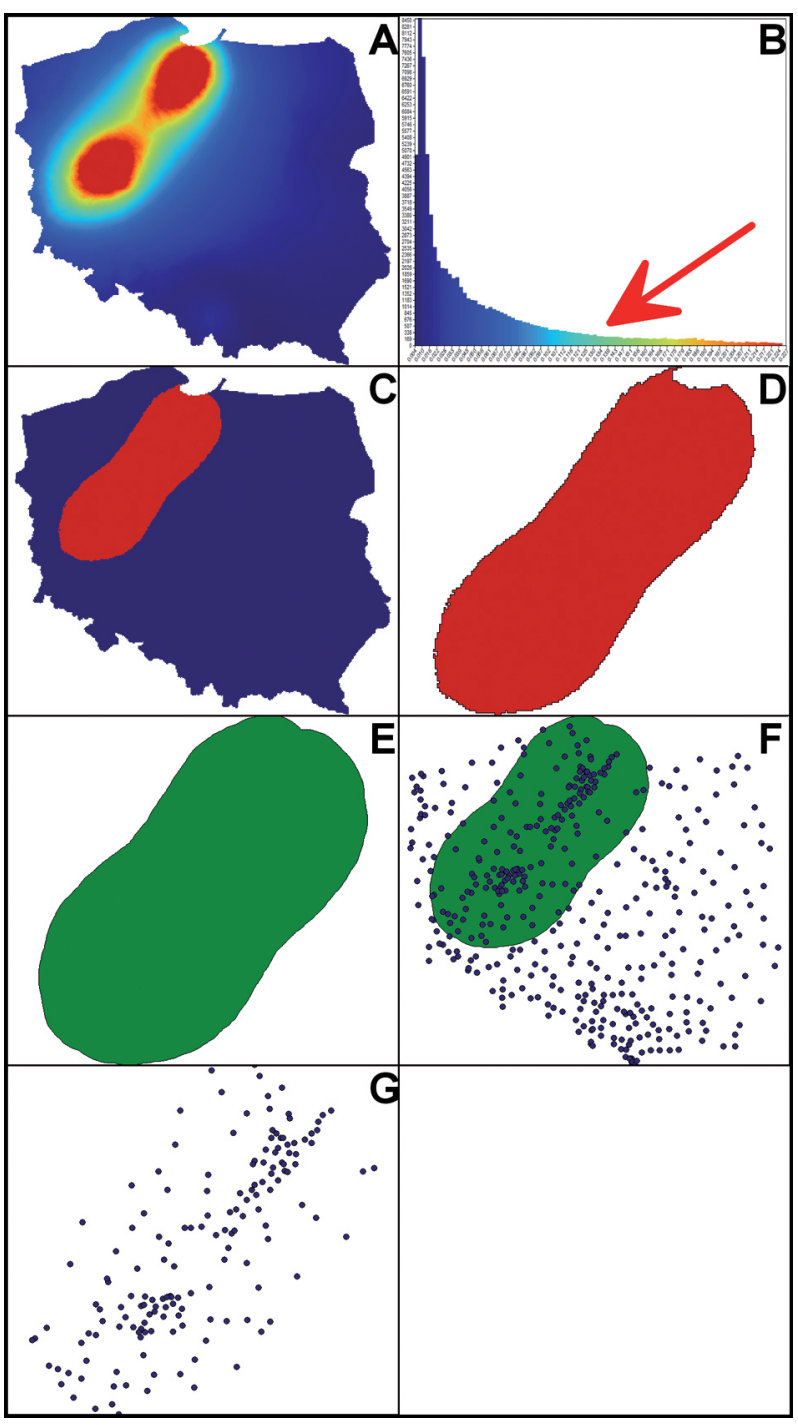

Fig. 3. Stages of EEDPT data preparation, an example from 20 July 1967. A: Map of kernel density estimation, B: Histogram of kernel density values, with arrow indicating threshold value, C: Reclassification map, D: Polygon of extensive precipitation area, E: Polygon of extensive precipitation enlarged to include 50-km wide zone, F: Dot map of precipitation stations together with extensive precipitation polygon enlarged to include 50-km wide zone, G: Dot map of precipitation stations lying in extensive precipitation area with their registered precipitation values, situated in the area obtained (Fig. 3F, 3G). On the basis of the set of data thus created, individual mean values, areas and perimeters of the precipitation field were determined. Also calculated was the precipitation volume as the product of the mean value and area of precipitation on the individual dates.

The first aim of the analysis was a quantitative verification of the hypothesis about the effect of a circulation situation on the probability of occurrence of an EEDPT. To this end use was made of the chi-2 test. A comparison of circulation situations against quantitative features of precipitation areas was another fundamental stage of the analysis. The small number of data imposed the use of methods belonging to non-parametric statistics: the Kruskal-Wallis test and multiple comparisons of mean ranks in groups (StatSoft 2006). This method also made it necessary to exclude from further calculations those circulation situations that appeared less than five times (Siegel, Castellan 1988 after Mundry, Fischer 1998), which eliminated six types of circulation data: HFZ, HM, HNFA, NA, SWA, and SWZ. In the case of the remaining ones, the hypothesis was advanced that the various circulation situations had different effects on the mean value, coefficient of variation, perimeter, area and volume of atmospheric precipitation.

\section{Results}

\section{Relation of circulation situations to dates of occurrence of EEDPTs}

All the data embracing the 1956-1980 period indicate that the most frequent synoptic situations were WZ (15.0\%), BM (7.8\%) and HM (7.4\%), and the rarest ones, NA (0.9\%), SZ (1.2\%), and NWA (1.3\%) (Fig. 4). Those frequencies were compared against the 209 EEDPT dates registered over the years 1956-1980. Their distribution turned out to be markedly different. While situations described as WZ appear here most often too $(15.3 \%)$, those closely following are TRW $(10 \%)$ and TRM $(7.4 \%)$. At the same time there have never been such situations as HNA, NWA, SA, SEA, SEZ, or SZ (Table 2). To determine the 


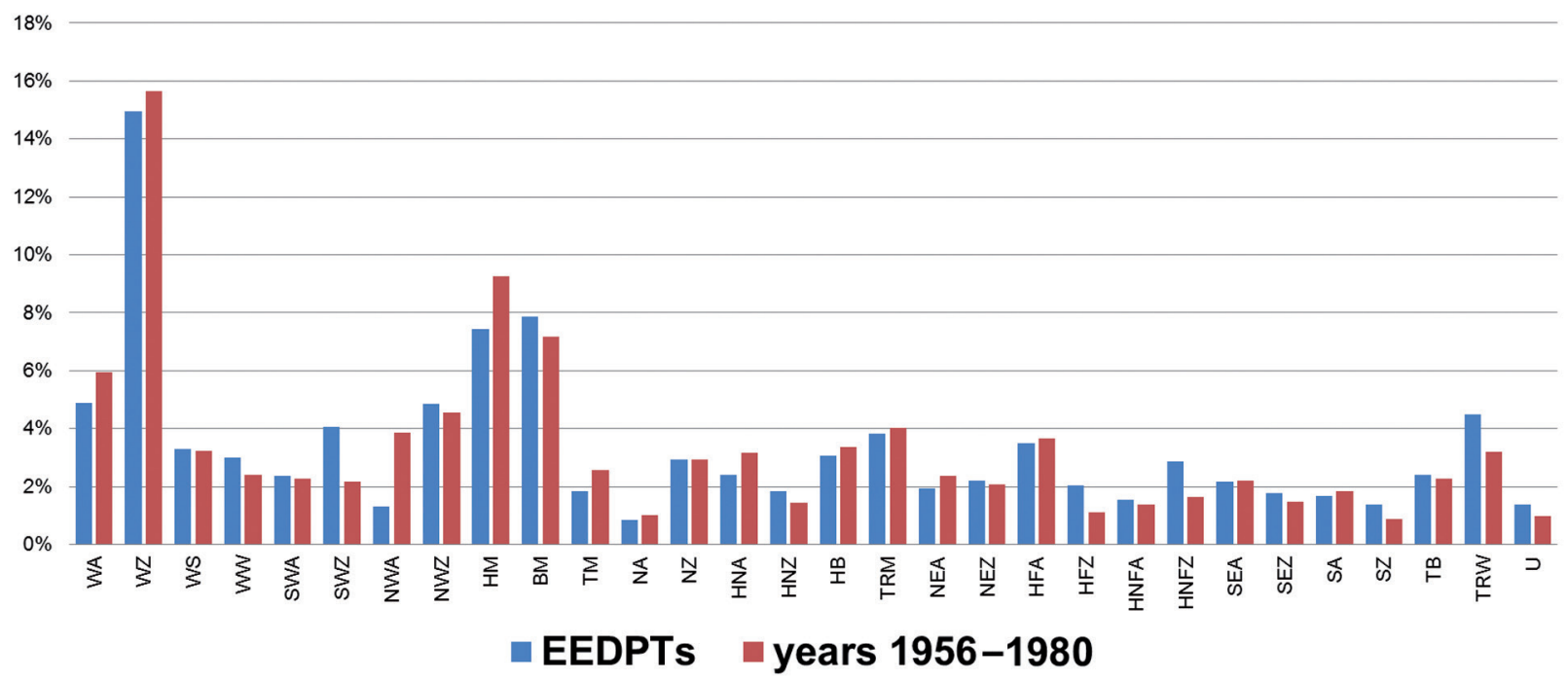

Fig. 4. Proportions of individual circulation situations from the Grosswetterlagen calendar in the entire 1956-1980 period (individual days) and on days with EEDPTs (abbreviations explained in Table 1)

significance of the differences in the frequency of the synoptic situation types during EEDPTs, a comparison was made of the observed and expected values. The results revealed statistically significant differences between situation types on the examined dates of extensive extreme precipitation and in the multi-year period. In particular, they are especially well marked for the NEZ, HM, TRM, HNZ, TRW and HNA situations.

The above result was corroborated using the chi-square test. It allowed assessing the significance of differences in the number of the individual types of synoptic situation between the EEDPT dates and the 1956-1980 period (StatSoft 2006). There were statistically significant differences for the situations NEZ, HM, TRM, HNZ, TRW, HNA, SEA, and SA (Table 3). In other cases the absence of statistically significant differences may be due to two reasons: either a similar number of occurrences of the given circulation situation on the EEDPT dates and in the 25-year period, or an insufficient number of data in the sample.

The relations between the number of the individual circulation situations on the dates under study and in the multi-year period make it possible to distinguish two groups of data (Fig. 5). In one the frequency of concrete circulation situations is markedly greater than in the multi-year period. It includes the following situations: 'north-east, cyclonic' (NEZ), 'Central European trough' (TRM), 'north, Iceland high, cyclon- ic' (HNZ), and 'West European trough' (TRW). They are registered almost two to four times more often on days with extensive maximum daily precipitation totals than in the entire 19561980 period. Two of them (TRM and TRW) are low-pressure troughs extending over Central Europe. What the other two (NEZ and HNZ) have in common is an extensive high often stretching from the Azores to Scandinavia but not embracing Poland, and a cyclonic system of winds. In the other group embracing the circulation situations 'Central European high' (HM), 'north, Iceland high, anticyclonic' (HNA), 'south-east, anticyclonic' (SEA), and 'south, anticyclonic' (SA), the frequency of concrete circulation situations is lower than in the multi-year period. This justifies the conclusion that the HM, HNA, SEA and SA situations are not favourable to the occurrence of extensive and efficient daily precipitation. What connects HM, HNA, SEA and SA is the appearance of a high over Central Europe and an anticyclonic system of winds (Gerstengarbe et al. 1999).

Many natural phenomena are observed to lag behind the moment when their cause has occurred. This is also the property of atmospheric precipitation. Hence it was decided to examine circulation situations two days before the relevant date and a day after it. They were termed additional days. The set of circulation situations obtained in this way (the relevant days plus the additional ones) included 659 dates and was compared against the entire 25-year period (Table 2). 
This group of dates was also examined using the chi-2 test for the significance of differences. The results showed several circulation situations in the group to differ significantly from those for the entire 1956-1980 period.
The results obtained for EEDPTs including the additional days embrace all cases significantly different for EEDPT dates alone as well as eight situations previously insignificant (Table 3, Fig. 6). Half of them (SWA, SWZ, SEZ and SZ) probably did not show significant differences in the set

Table 2. Absolute number and proportion of individual circulation situations from the Grosswetterlagen classification in the entire 1956-1980 period, on days with EEDPTs plus additional days, and on days with EEDPTs only. Detailed description in the text

\begin{tabular}{|c|c|c|c|c|c|c|}
\hline $\begin{array}{l}\text { Circulation } \\
\text { type }\end{array}$ & Years 1956-1980 & $\begin{array}{l}\text { EEDPTs plus } \\
\text { additional } \\
\text { dates }\end{array}$ & EEDPTs & $\begin{array}{c}\text { Years } 1956-1980 \\
\text { (in \%) }\end{array}$ & $\begin{array}{l}\text { EEDPTs plus } \\
\text { additional } \\
\text { dates (in \%) }\end{array}$ & EEDPTs (in \%) \\
\hline WA & 444 & 22 & 5 & 4.86 & 3.34 & 2.39 \\
\hline WZ & 1,365 & 101 & 30 & 14.95 & 15.33 & 14.35 \\
\hline WS & 299 & 34 & 9 & 3.27 & 5.16 & 4.31 \\
\hline WW & 274 & 24 & 10 & 3.00 & 3.64 & 4.78 \\
\hline SWA & 217 & 5 & 2 & 2.38 & 0.76 & 0.96 \\
\hline SWZ & 372 & 10 & 3 & 4.07 & 1.52 & 1.44 \\
\hline NWA & 118 & 3 & 0 & 1.29 & 0.46 & 0.00 \\
\hline NWZ & 444 & 25 & 10 & 4.86 & 3.79 & 4.78 \\
\hline $\mathrm{HM}$ & 678 & 9 & 2 & 7.42 & 1.37 & 0.96 \\
\hline $\mathrm{BM}$ & 716 & 31 & 11 & 7.84 & 4.70 & 5.26 \\
\hline $\mathrm{TM}$ & 168 & 17 & 7 & 1.84 & 2.58 & 3.35 \\
\hline NA & 78 & 7 & 3 & 0.85 & 1.06 & 1.44 \\
\hline NZ & 268 & 36 & 10 & 2.93 & 5.46 & 4.78 \\
\hline HNA & 219 & 2 & 0 & 2.40 & 0.30 & 0.00 \\
\hline HNZ & 167 & 29 & 10 & 1.83 & 4.40 & 4.78 \\
\hline HB & 278 & 17 & 7 & 3.04 & 2.58 & 3.35 \\
\hline TRM & 350 & 49 & 17 & 3.83 & 7.44 & 8.13 \\
\hline NEA & 178 & 17 & 6 & 1.95 & 2.58 & 2.87 \\
\hline NEZ & 200 & 36 & 16 & 2.19 & 5.46 & 7.66 \\
\hline HFA & 319 & 25 & 7 & 3.49 & 3.79 & 3.35 \\
\hline HFZ & 186 & 10 & 3 & 2.04 & 1.52 & 1.44 \\
\hline HNFA & 140 & 7 & 2 & 1.53 & 1.06 & 0.96 \\
\hline HNFZ & 261 & 27 & 7 & 2.86 & 4.10 & 3.35 \\
\hline SEA & 199 & 2 & 0 & 2.18 & 0.30 & 0.00 \\
\hline SEZ & 161 & 1 & 0 & 1.76 & 0.15 & 0.00 \\
\hline SA & 173 & 0 & 0 & 1.89 & 0.00 & 0.00 \\
\hline SZ & 107 & 1 & 0 & 1.17 & 0.15 & 0.00 \\
\hline TB & 218 & 35 & 8 & 2.39 & 5.31 & 3.83 \\
\hline TRW & 409 & 66 & 18 & 4.48 & 10.02 & 8.61 \\
\hline $\mathrm{U}$ & 126 & 11 & 6 & 1.38 & 1.67 & 2.87 \\
\hline total & 9,132 & 659 & 209 & 100.00 & 100.00 & 100.00 \\
\hline
\end{tabular}


of EEDPTs because of the small size of the sample. NZ, WS and especially TB occur markedly more often on EEDPT dates plus additional days than in the entire multi-year period. What those situations have in common is a cold atmospheric front passing over Central Europe from the north or north-west. This can imply that they come in advance of extreme daily precipitation events of a large spatial extent. On the other hand, a BM situation occurs much more rarely in the case of EEDPT dates plus additional days than over the entire multi-year period. This is due to the appearance of an extensive zone of high pressure over the central part of Europe. The recorded cases of extreme precipitation during BM situations result, as suggested by Ustrnul and Czekierda (2001), from the occurrence of very heavy, torrential rains exceeding $150 \mathrm{~mm}$ per hour in intensity.

An important element of the research was checking the effect of seasonal variations in the occurrence of GWL circulation types against the EEDPT dates. The dates under study only occurred from April to November. This seasonal distribution could affect the frequency of GWL types in relation to the entire multi-year period. Therefore a comparison was made of the frequency of EEDPTs against (1) circulation situations between April and November, and (2) circulation situations on analogous days of the year.

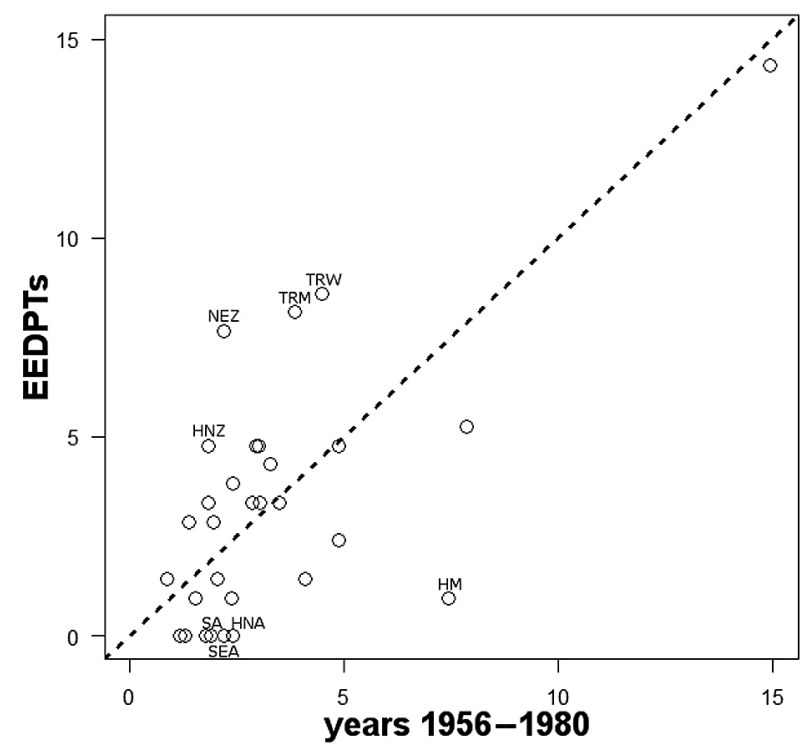

Fig. 5. Proportion of selected circulation types from the Grosswetterlagen classification in the entire 1956-1980 period and on the 209 EEDPT dates. Circulation situations differing significantly $(\mathrm{p}<0.05)$ are described in the diagram using abbreviations
To examine the effect of the seasonal variation in the GWL circulation types on the occurrence of EEDPTs, out of the entire database embracing the

Table 3. Results of testing the significance of differences in the frequency of circulation situations in two-way tables using the chi-2 test for: A: EEDPT dates and the entire 1956-1980 period, B: EEDPT plus additional dates and the entire 1956-1980 period, C: EEDPT dates and the season (2 April-22 Nov.) in the years 1956-1980, D: EEDPT dates and analogous dates in the years 1956-1980. Statistically significant results $(p<0.05)$ are given in boldface

\begin{tabular}{|c|c|c|c|c|}
\hline $\begin{array}{c}\text { Circu- } \\
\text { lation } \\
\text { situation }\end{array}$ & A & B & $\mathrm{C}$ & $\mathrm{D}$ \\
\hline WA & $\mathrm{p}=.0989$ & $p=.0760$ & $p=.0361$ & $p=.0126$ \\
\hline WZ & $\mathrm{p}=.8119$ & $\mathrm{p}=.7924$ & $\mathrm{p}=.9461$ & $\mathrm{p}=.8279$ \\
\hline WS & $\mathrm{p}=.4087$ & $p=.0099$ & $\mathrm{p}=.0534$ & $\mathrm{p}=.1981$ \\
\hline WW & $\mathrm{p}=.1374$ & $\mathrm{p}=.3546$ & $\mathrm{p}=.0920$ & $\mathrm{p}=.0443$ \\
\hline SWA & $\mathrm{p}=.1800$ & $\mathrm{p}=.0071$ & $\mathrm{p}=.1775$ & $\mathrm{p}=.1382$ \\
\hline SWZ & $\mathrm{p}=.0547$ & $\mathrm{p}=.0011$ & $\mathrm{p}=.1004$ & $\mathrm{p}=.4194$ \\
\hline NWA & $\mathrm{p}=.0982$ & $p=.0604$ & $\mathrm{p}=.0929$ & $p=.0429$ \\
\hline NWZ & $\mathrm{p}=.9590$ & $\mathrm{p}=.2149$ & $\mathrm{p}=.9542$ & $\mathrm{p}=.7769$ \\
\hline HM & $\mathrm{p}=.0004$ & $\mathrm{p}=.0000$ & $\mathrm{p}=.0002$ & $p=.0003$ \\
\hline $\mathrm{BM}$ & $\mathrm{p}=.1691$ & $\mathrm{p}=.0034$ & $\mathrm{p}=.1801$ & $\mathrm{p}=.1460$ \\
\hline $\mathrm{TM}$ & $\mathrm{p}=.1115$ & $\mathrm{p}=.1779$ & $\mathrm{p}=.1618$ & $\mathrm{p}=.0347$ \\
\hline NA & $\mathrm{p}=.3702$ & $\mathrm{p}=.5782$ & $\mathrm{p}=.5468$ & $\mathrm{p}=.4882$ \\
\hline $\mathrm{NZ}$ & $\mathrm{p}=.1197$ & $\mathrm{p}=.0003$ & $\mathrm{p}=.0683$ & $\mathrm{p}=.0543$ \\
\hline HNA & $\mathrm{p}=.0235$ & $\mathrm{p}=.0005$ & $p=.0164$ & $p=.0149$ \\
\hline $\mathrm{HNZ}$ & $\mathrm{p}=.0019$ & $\mathrm{p}=.0000$ & $p=.0002$ & $p=.0206$ \\
\hline $\mathrm{HB}$ & $\mathrm{p}=.7999$ & $\mathrm{p}=.5005$ & $\mathrm{p}=.7085$ & $\mathrm{p}=.4152$ \\
\hline TRM & $p=.0016$ & $\mathrm{p}=.0000$ & $p=.0016$ & $p=.0000$ \\
\hline NEA & $\mathrm{p}=.3431$ & $\mathrm{p}=.2632$ & $\mathrm{p}=.7583$ & $\mathrm{p}=.9769$ \\
\hline NEZ & $\mathrm{p}=.0000$ & $p=.0000$ & $p=.0000$ & $p=.0003$ \\
\hline HFA & $\mathrm{p}=.9107$ & $\mathrm{p}=.6858$ & $\mathrm{p}=.8443$ & $\mathrm{p}=.5141$ \\
\hline $\mathrm{HFZ}$ & $\mathrm{p}=.5415$ & $\mathrm{p}=.3580$ & $\mathrm{p}=.5350$ & $\mathrm{p}=.6342$ \\
\hline HNFA & $\mathrm{p}=.5009$ & $\mathrm{p}=.3371$ & $\mathrm{p}=.4232$ & $\mathrm{p}=.3610$ \\
\hline HNFZ & $\mathrm{p}=.6741$ & $\mathrm{p}=.0691$ & $\mathrm{p}=.7199$ & $\mathrm{p}=.3318$ \\
\hline SEA & $\mathrm{p}=.0310$ & $\mathrm{p}=.0010$ & $\mathrm{p}=.0775$ & $\mathrm{p}=.1357$ \\
\hline SEZ & $\mathrm{p}=.0528$ & $\mathrm{p}=.0017$ & $\mathrm{p}=.1669$ & $\mathrm{p}=.2844$ \\
\hline SA & $p=.0446$ & $p=.0004$ & $p=.0475$ & $\mathrm{p}=.1943$ \\
\hline SZ & $\mathrm{p}=.1155$ & $\mathrm{p}=.0155$ & $\mathrm{p}=.2304$ & $\mathrm{p}=.3825$ \\
\hline $\mathrm{TB}$ & $\mathrm{p}=.1802$ & $\mathrm{p}=.0000$ & $\mathrm{p}=.5078$ & $\mathrm{p}=.6214$ \\
\hline TRW & $\mathrm{p}=.0047$ & $\mathrm{p}=.0000$ & $\mathrm{p}=.0737$ & $\mathrm{p}=.1184$ \\
\hline $\mathrm{U}$ & $\mathrm{p}=.0710$ & $\mathrm{p}=.5413$ & $\mathrm{p}=.1228$ & $\mathrm{p}=.0864$ \\
\hline
\end{tabular}


study period (9,132 days) a selection was made of dates corresponding to the period from 2 April to 22 November in each of the years 1956-1980 (5,850 days) (Table 4). Those were dates of the earliest and the latest occurrence of extensive maximum precipitation in the multi-year period. Next the significance of differences between

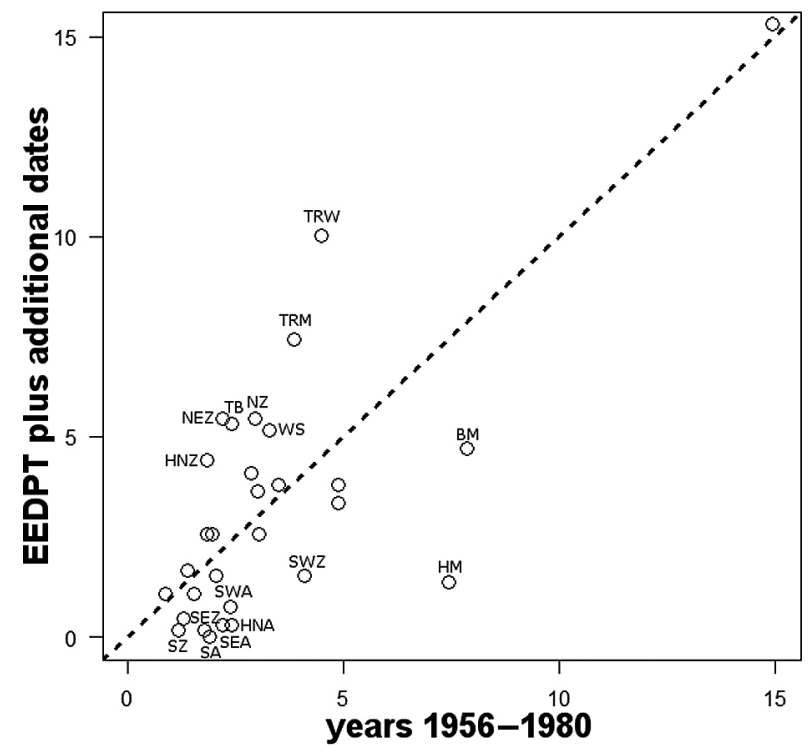

Fig. 6. Proportion of selected circulation types from the Grosswetterlagen classification in the entire 1956-1980 period and on the 209 EEDPT dates plus 450 additional dates.

Circulation situations differing significantly $(p<0.05)$ are described in the diagram using abbreviations

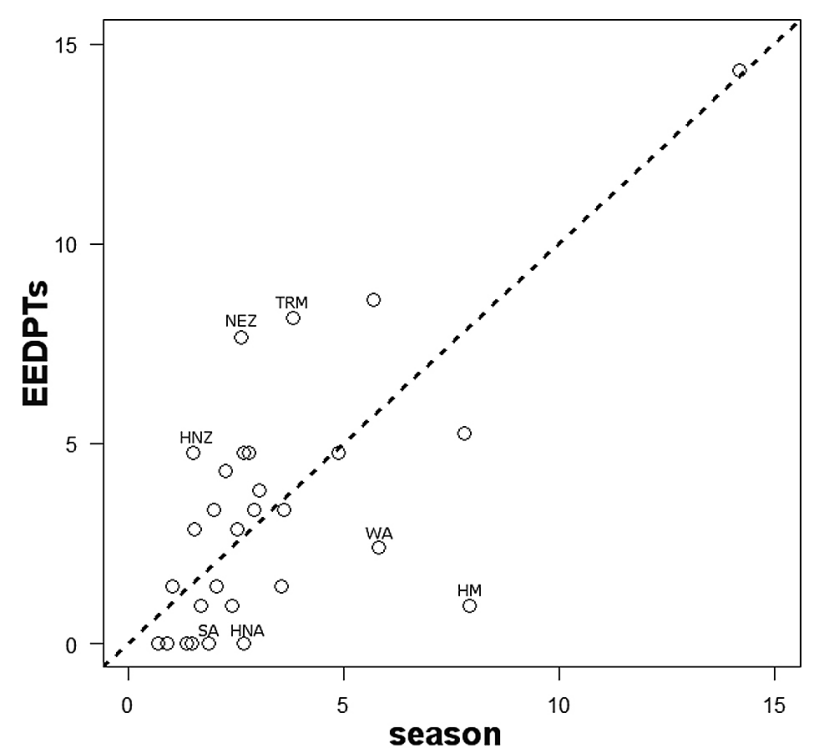

Fig. 7. Proportion of selected circulation types from the Grosswetterlagen classification in the selected season over the years 1956-1980 and on the 209 EEDPT dates. Circulation situations differing significantly $(p<0.05)$ are described in the diagram using abbreviations the frequencies of circulation situations on the EEDPT dates and in the selected season was tested. It was demonstrated that there were several GWL types significantly differing in the dates of occurrence of extensive maximum precipitation

Table 4. Absolute number and proportion of individual circulation situations from the Grosswetterlagen calendar in the selected season on analogous dates of the entire 1956-1980 period and on the EEDPT dates.

Detailed description in the text

\begin{tabular}{|l|c|c|c|c|c|c|}
\hline $\begin{array}{c}\text { Circula- } \\
\text { tion } \\
\text { type }\end{array}$ & $\begin{array}{c}\text { Sea- } \\
\text { son }\end{array}$ & $\begin{array}{c}\text { Anal- } \\
\text { ogous } \\
\text { dates }\end{array}$ & EEDPTs & $\begin{array}{c}\text { Season } \\
\text { (in } \% \text { ) }\end{array}$ & $\begin{array}{c}\text { Anal- } \\
\text { ogous } \\
\text { dates } \\
\text { (in \%) }\end{array}$ & $\begin{array}{c}\text { EEDPTs } \\
\text { (in \%) }\end{array}$ \\
\hline WA & 340 & 187 & 5 & 5,81 & 6,8 & 2,39 \\
\hline WZ & 830 & 410 & 30 & 14,19 & 14,91 & 14,35 \\
\hline WS & 132 & 76 & 9 & 2,26 & 2,76 & 4,31 \\
\hline WW & 164 & 68 & 10 & 2,8 & 2,47 & 4,78 \\
\hline SWA & 140 & 72 & 2 & 2,39 & 2,62 & 0,96 \\
\hline SWZ & 208 & 63 & 3 & 3,56 & 2,29 & 1,44 \\
\hline NWA & 78 & 53 & 0 & 1,33 & 1,93 & 0 \\
\hline NWZ & 285 & 144 & 10 & 4,87 & 5,24 & 4,78 \\
\hline HM & 463 & 212 & 2 & 7,91 & 7,71 & 0,96 \\
\hline BM & 455 & 222 & 11 & 7,78 & 8,07 & 5,26 \\
\hline TM & 115 & 40 & 7 & 1,97 & 1,45 & 3,35 \\
\hline NA & 59 & 26 & 3 & 1,01 & 0,95 & 1,44 \\
\hline NZ & 157 & 70 & 10 & 2,68 & 2,55 & 4,78 \\
\hline HNA & 157 & 76 & 0 & 2,68 & 2,76 & 0 \\
\hline HNZ & 88 & 53 & 10 & 1,5 & 1,93 & 4,78 \\
\hline HB & 170 & 67 & 7 & 2,91 & 2,44 & 3,35 \\
\hline TRM & 223 & 87 & 17 & 3,81 & 3,16 & 8,13 \\
\hline NEA & 148 & 78 & 6 & 2,53 & 2,84 & 2,87 \\
\hline NEZ & 153 & 83 & 16 & 2,62 & 3,02 & 7,66 \\
\hline HFA & 211 & 118 & 7 & 3,61 & 4,29 & 3,35 \\
\hline HFZ & 120 & 67 & 3 & 2,05 & 2,44 & 1,44 \\
\hline HNFA & 98 & 50 & 2 & 1,68 & 1,82 & 0,96 \\
\hline HNFZ & 171 & 63 & 7 & 2,92 & 2,29 & 3,35 \\
\hline SEA & 86 & 29 & 0 & 1,47 & 1,05 & 0 \\
\hline SEZ & 53 & 15 & 0 & 0,91 & 0,55 & 0 \\
\hline SA & 108 & 22 & 0 & 1,85 & 0,8 & 0 \\
\hline SZ & 40 & 10 & 0 & 0,68 & 0,36 & 0 \\
\hline TB & 177 & 88 & 8 & 3,03 & 3,2 & 3,83 \\
\hline TRW & 332 & 163 & 18 & 5,68 & 5,93 & 8,61 \\
\hline U & 89 & 38 & 6 & 1,52 & 1,38 & 2,87 \\
\hline 5,850 & 2,750 & 209 & 100 & 100 & 100 \\
\hline
\end{tabular}


from the entire season (Table 3). They mostly coincided with situations compared against the entire 25-year period, the only exceptions being WA and TRW situations. The proportion of WA on EEDPT dates significantly differed from the figure for the entire season. This situation happened more often between 2 April and 22 November $(5.81 \%)$ than in the $1956-1980$ period $(4.86 \%)$. At the same time it was registered fairly rarely on EEDPT dates (2.39\%). The results obtained for the TRW situation look different. Its number on the dates of occurrence of EEDPTs was significant in terms of the entire 25-year period, but insignificant in terms of the season. The earlier TRW result was an effect of a seasonal variation in this type of circulation situation. As a consequence, the TRW situation cannot be taken into consideration as a significant cause of extensive extreme precipitation.

To compare the frequency of EEDPTs against circulation situations occurring on analogous days of the year, the day of the year with an EEDPT event was given a number. In this way a set of data was created embracing circulation situations for day numbers in the year over the entire multi-year period analogous to EEDPT dates. In effect, 2,750 dates were chosen, which corresponds to 110 days for each of the years. In the

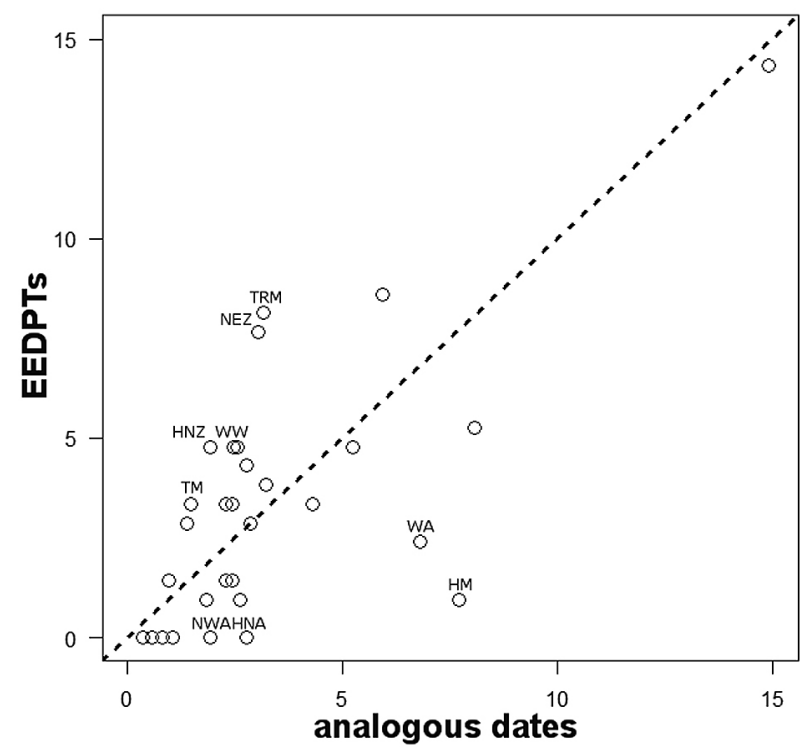

Fig. 8. Proportion of selected circulation types from the Grosswetterlagen classification on analogous dates over the years 1956-1980 and on the 209 EEDPT dates. Circulation situations differing significantly $(p<0.05)$ are described in the diagram using abbreviations analysis use was also made of a comparison of observed to expected values and of the chi-2 test. The latter turned out to be statistically significant in the case of nine circulation situations (Table 3). Three of them (WW, NWA and TM) were not statistically significant on previous examination. This suggests that they occur significantly more often during extensive extreme precipitation events than on the same dates in the multi-year period. The WW and TM situations appear more often during EEDPTs than on analogous dates. A characteristic of a WW is an inflow of air masses from the west and the formation of a frontal zone over Poland, while a TM situation involves a wide-ranging low over Central Europe. On the other hand, an NWA situation did not appear even once on EEDPT dates, but was registered in almost $2 \%$ of cases of analogous dates. As in the previous calculations, TRM, HNZ and NEZ were much more frequent. In turn, HNA, HM and WA situations were observed markedly more rarely on EEDPT dates than on analogous days of the year (Fig. 8).

\section{Relationship between circulation situations and EEDPT features}

Extensive extreme precipitation was described using such features as mean precipitation, coefficient of precipitation variation, as well as the area, perimeter and volume of precipitation. The median, interquartile range, as well as the ranges and most outlying values of those EEDPT features are presented in Figure 9.

The number of data in the EEDPT database embraced from 74 measuring sites on 10 June 1959 to 609 measuring sites on 4 August 1979. On the individual 209 EEDPT dates, the mean atmos-

Table 5. Significance of the relation between selected circulation situations and individual EEDPT variables. Statistically significant results $(p<0.05)$ are given in boldface

\begin{tabular}{|l|c|}
\hline \multicolumn{1}{|c|}{ Variable } & $\mathrm{p}$-value \\
\hline mean precipitation & $\mathbf{0 . 0 3 6 2}$ \\
\hline coefficient of precipitation variation & $\mathbf{0 . 0 0 5 4}$ \\
\hline volume & $\mathbf{0 . 0 0 8 1}$ \\
\hline perimeter & 0.3633 \\
\hline area & 0.3757 \\
\hline
\end{tabular}


pheric precipitation total varied from almost 13 mm on 2 April 1973 to more than $90 \mathrm{~mm}$ on 18 July 1970. The lowest coefficient of variation, at 0.2 , fell on 16 October 1974, and the highest, at 1.2, on 2 April 1973. The precipitation area covered from 44.6 thous. $\mathrm{km}^{2}$ on 13 October 1966 to 249.7 thous. $\mathrm{km}^{2}$ on 18 September 1962, at perimeters of $752 \mathrm{~km}$ and 2,156 km, respectively. The EEDPT volume ranged from $1.2 \mathrm{~km}^{3}$ on 28 July 1961 to $7.6 \mathrm{~km}^{3}$ on 8 August 1978. All those EEDPT features display both a high scatter of values, and a clearly right-skewed distribution.
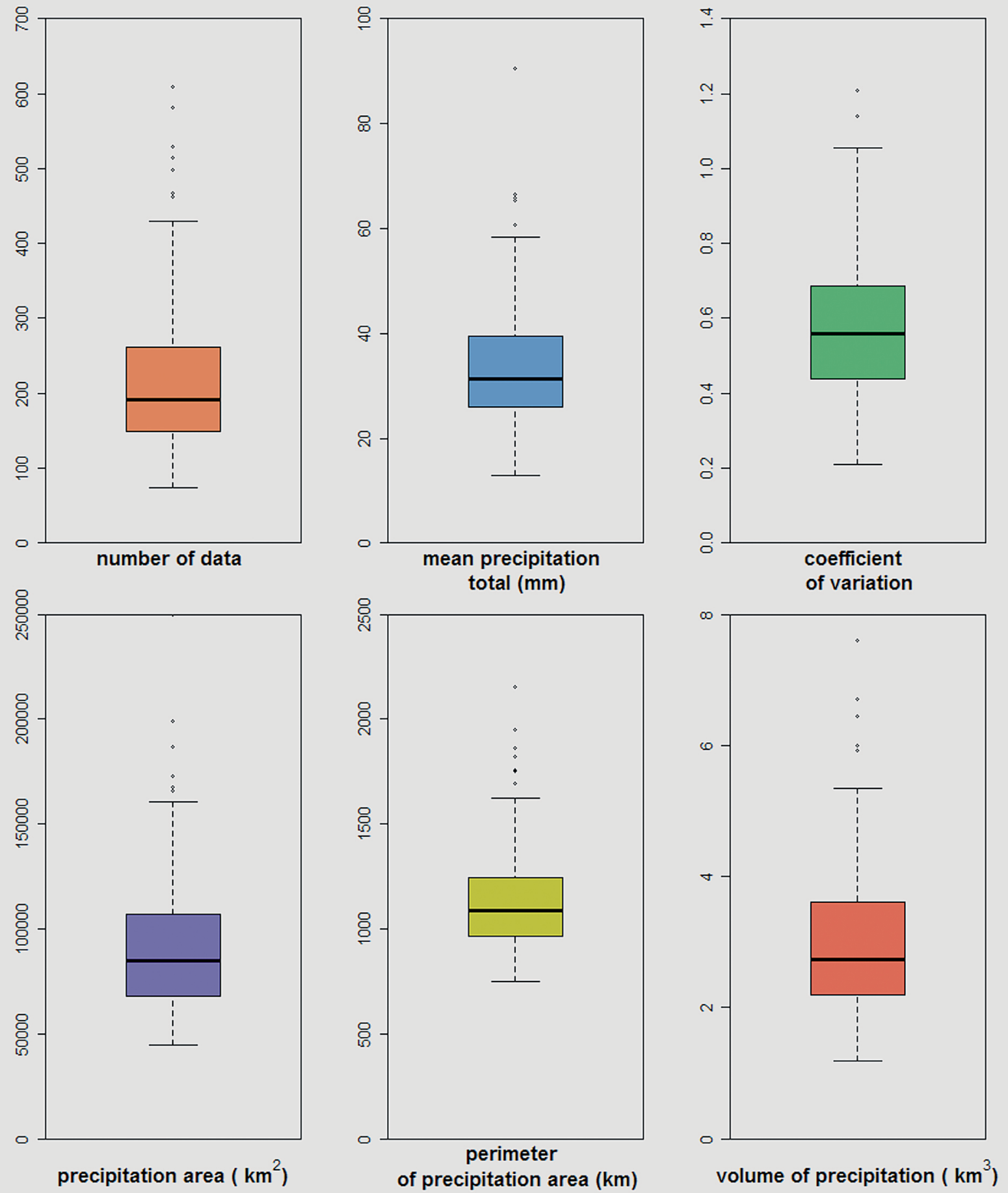

Fig. 9. Number of data, mean precipitation total, coefficient of precipitation variation, precipitation area, perimeter of the precipitation area, volume of the EEDPT data 
The hypothesis was put forward that the EEDPT features differed significantly depending on the circulation situation. In the 25-year period extensive precipitation was found to oc-

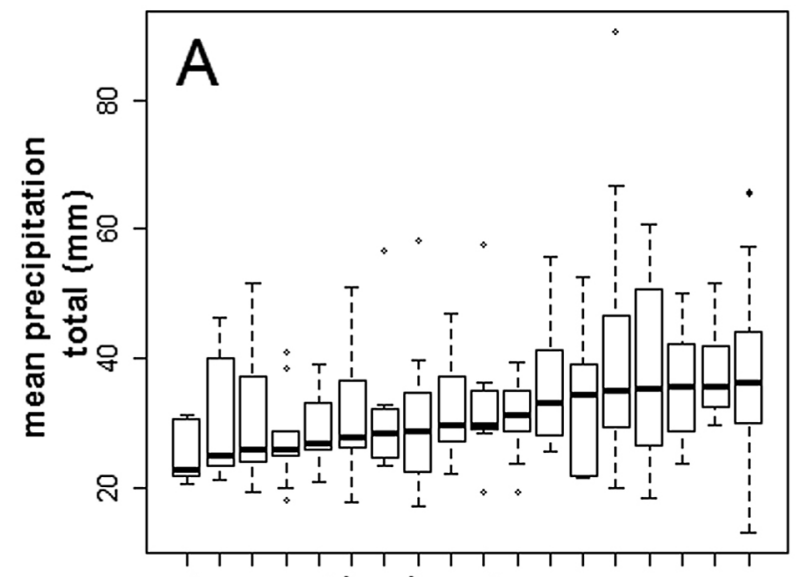

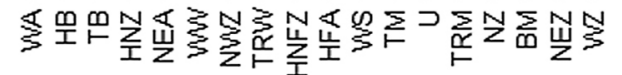
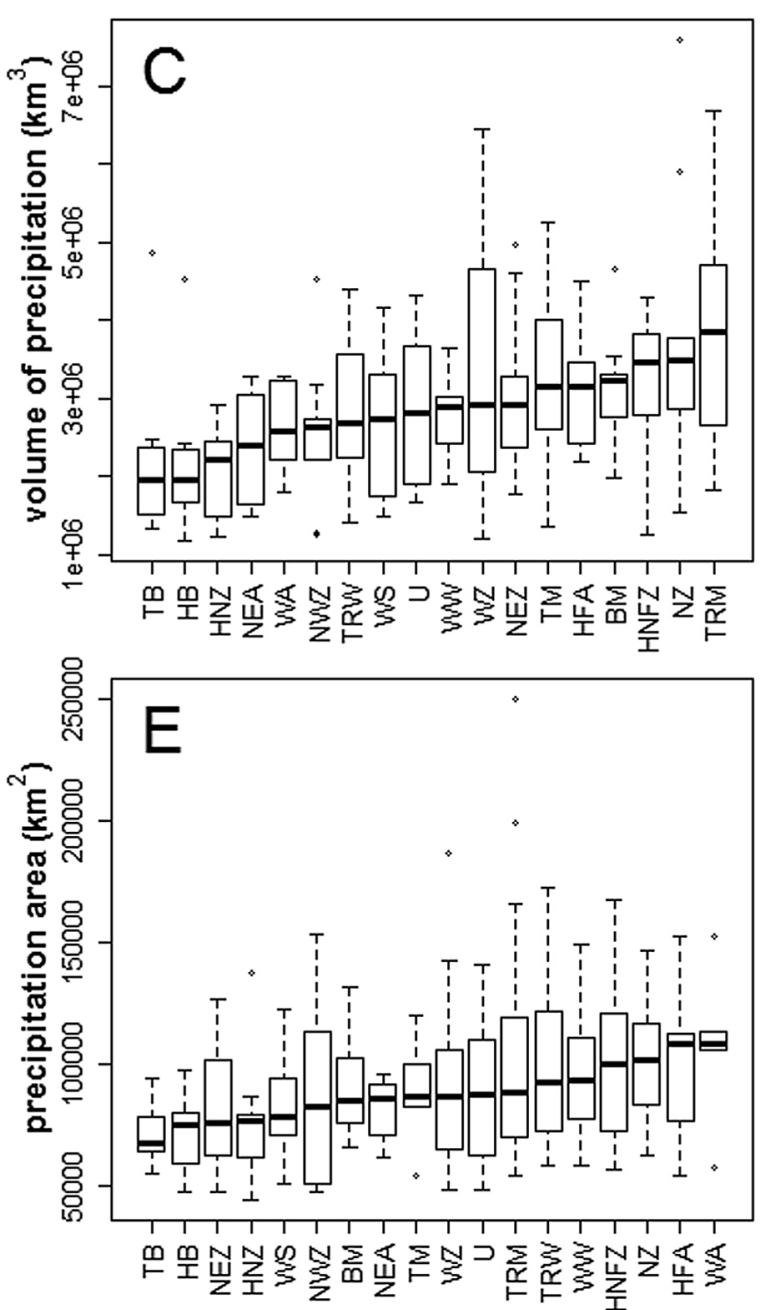

cur 209 times. On those dates there were twenty four different circulation situations, of which six appeared less than five times: HFZ, HM, HNFA, NA, SWA, and SWZ. They were eliminated from
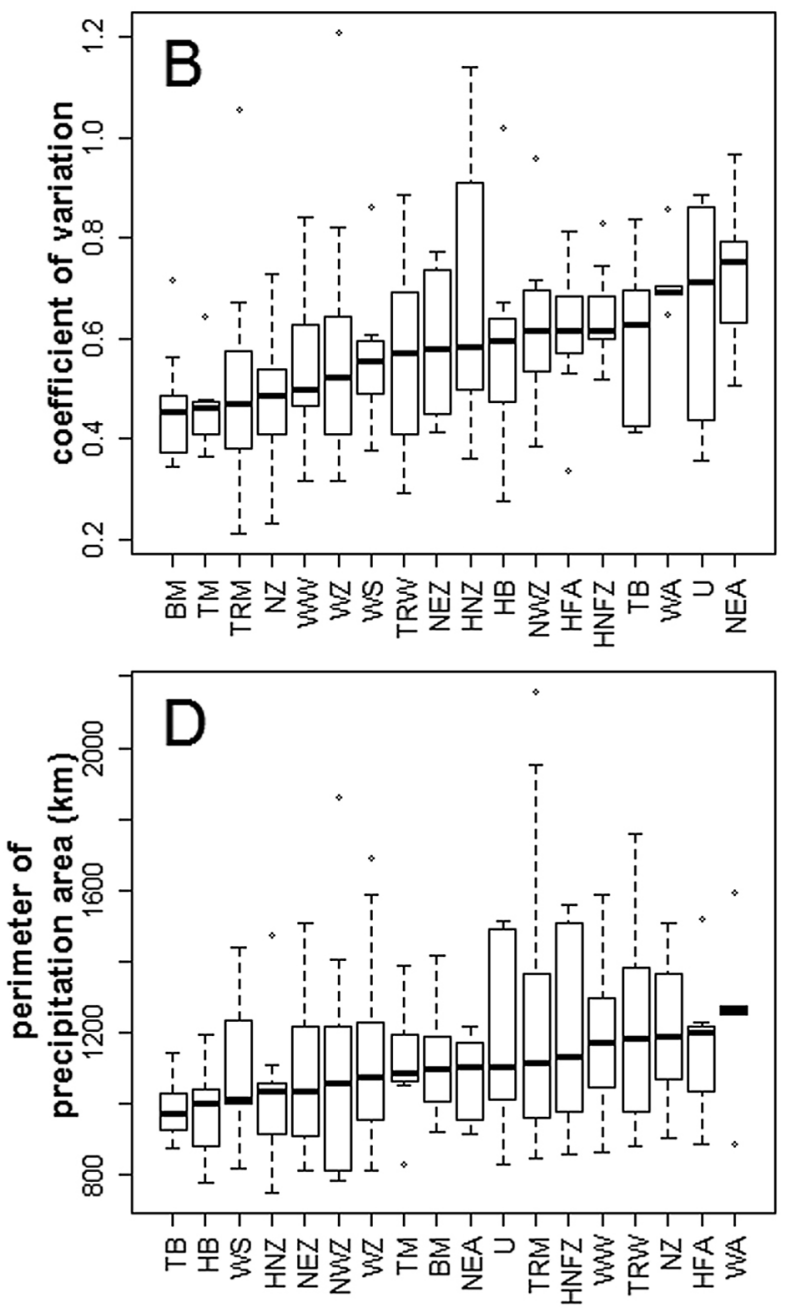

Fig. 10. Variations of the EEDPT features within individual Grosswetterlagen circulation situations: A: mean precipitation, B: coefficient of variation, C: volume, D: perimeter, E: area 
further calculations because this is a quantity insufficient for the purposes of non-parametric statistics (Siegel, Castellan 1988 after Mundry, Fischer 1998). There were eighteen circulation situations noted more than five times: $\mathrm{BM}, \mathrm{HB}$, HFA, HNFZ, HNZ, NEA, NEZ, NWZ, NZ, TB, TM, TRM, TRW, U, WA, WS, WW, and WZ. Using the Kruskal-Wallis test, they were compared in terms of mean precipitation, coefficient of variation, standard deviation, area, perimeter and volume of precipitation. The results (Table 5) suggest statistically significant differences among the above circulation situations in terms of the mean EEDPT value, its volume, and the coefficient of precipitation variation.

The results presented in Figures 10A, 10B and 10C show there to be significant variations in the individual precipitation features - mean, coefficient of variation and volume - among the GWL circulation situations. A post-hoc test of multiple comparisons of mean ranks for all groups was performed for those EEDPT features. In the case of mean precipitation and the coefficient of variation, it did not show significant differences between the successive pairs of circulation situations. A statistically significant difference only appeared in the case of the precipitation volume and involved TRM and HNZ situations. Precipitation registered in a TRM situation had the greatest mean volume $\left(3.84 \mathrm{~km}^{3}\right)$ and the highest standard deviation of the volume $\left(1.38 \mathrm{~km}^{3}\right)$, while that occurring in a HNZ situation showed the lowest mean volume $\left(2.04 \mathrm{~km}^{3}\right)$ and a relatively slight standard deviation of the volume $\left(0.59 \mathrm{~km}^{3}\right)$ (Fig. 10C). It was not possible to indicate any circulation situation producing statistically significant differences in mean precipitation and in the coefficient of precipitation variation, and in the set of EEDPT volumes only one pair of significantly differing circulation situations were discovered. This result is due to the small number of EEDPT data. Moreover, most of the EEDPT cases (195 of 209) extended beyond the borders of Poland. A study of extensive extreme precipitation on larger study areas over longer time spans should reveal more pairs of circulation situations significantly differing not only in terms of the volume, but also mean precipitation and the coefficient of variation of EEDPTs.

\section{Conclusions}

The results obtained make it possible to trace some regularities. A marked effect on the occurrence of extensive extreme daily precipitation totals is exerted by atmospheric circulation. Factors favourable to such events are a low-pressure system and the contact of warm and cold air masses. A cyclonic system of winds also often plays a major role in the formation of EEDPTs. This corroborates the results obtained by Łupikasza (2010a), who found cyclonic types of circulation based on the classifications by Niedźwiedź and Ustrnul to have a significant effect on the occurrence of high precipitation totals. In turn, on days when extreme precipitation is recorded rarely or never, there is an anticyclonic wind system. Worth emphasising is the fact that an EEDPT was recorded very rarely in circulation situations involving southern advection. It was also demonstrated that circulation situations preceding and following the days with extensive maximum precipitation usually displayed similar features. It was, however, possible to observe a cold front from the north or north-west influencing the formation of an EEDPT. The final finding of the analysis of pressure systems was that some Grosswetterlagen circulation situations for EEDPT dates differed significantly from those situations recorded for dates between April and November.

The hypothesis that the circulation situation had an impact on precipitation features was corroborated for mean values, the coefficient of variation and volume of precipitation, which differed significantly among circulation situations. However, one should be aware of the imperfection of the calculations performed. Because of the small set of data, a non-parametric statistical method was employed and calculations were made for a part of possible circulation types. Still, the results obtained justify the claim that individual circulation situations (i.e., the direction of inflow of air masses, the location of high- and low-pressure systems, and the direction of rotation) can not only cause the occurrence of EEDPTs, but also determine their amount. This issue, however, requires a more detailed analysis based on a much greater number of cases. 


\section{References}

Bogucka M., 1998. Extreme rainfalls in Poland in the last 30 years. In: Proceedings of the 2nd European Conference on Applied Climatology, Österreichische Beiträge zu Meteorologie und Geodynamik (ZAMG), Vienna, Austria, Publ. 384.

Cebulak E., 1992. The influence of synoptic situations on the maximum daily precipitation in the upper Vistula basin. Folia Geographica, Ser. Geographica Physica 23: 81-95.

Gerstengarbe F.W., Werner P.C., Rüge U., 1999. Katalog der Grosswetterlagen Europas (1881-1998) Nach Paul Hess und Helmuth Berezowski. Potsdam, Offenbach a. M.

Heino R., Brazdil R., Forland E., Tuomenvirta H., Alexandersson H., Beniston M., Pfister C., Rebetez M., Rosenhagen G., Rosner S., Wibig J. 1999. Progress in the study of climatic extremes in northern and central Europe. Climatic Change 42(1): 151-181.

Isaaks E.H., Srivastava R.M., 1989. Applied Geostatistics. Oxford Univeristy Press, New York.

James P.M., 2006. An objective classification methods for Hess and Berezowsky Grosswetterlangen over Europe. Theoretical and Applied Climatology 88: 17-42.

Kożuchowski K., 1986: Variation in the precipitation in the years 1881-1980 in Poland. Acta Univ. Lodziensis, Folia Geographica 48: 158 pp.

Kwiatkowski J., 1984. Relationship between atmospheric precipitation in the Polish Sudety Mts. and its foreland and circulation factors. PAN, Komisja Nauk o Ziemi, Wrocław, 137 pp.

Lauangthong O., McLennan J.A., Deutsch C.V., 2004. Minimum acceptance criteria for geostatistical realizations. Natural Resources Research 13: 131-141.

Levine N., 2010. CrimeStat: A Spatial Statistics Program for the Analysis of Crime Incident Locations (v 3.3). Ned Levine \& Associates, Houston, TX, and the National Institute of Justice, Washington, DC.

Łupikasza E., 2010a. Relationships between occurrence of high precipitation and atmospheric circulation in Poland using different classifications of circulation types. Physics and Chemistry of the Earth 35: 448-455.

Łupikasza E., 2010b. Spatial and temporal variability of extreme precipitation in Poland in the period 1951-2006. Int. J. Climatol. 30: 991-1007.

Łupikasza E.B., Hänsel S., Matschullat J., 2011. Regional and seasonal variability of extreme precipitation trends in southern Poland and central-eastern Germany 19512006. Int. J. Climatol., 31: 2249-2271.

International Commission for the Protection of the Odra River against Pollution, 1999. Dorzecze Odry. Powódź: 1-56.
Morawska-Horawska M., 1971. Meteorological causes of the flood in the Southern Poland in July 1970. Przeglad Geofizyczny 16: 229-315.

Mrugała S., 2001. Opady atmosferyczne o normalnej i anomalnej wysokości na obszarze Polski (1951-1990). Wydawnictwo Uniwersytetu Marii Curie-Skłodowskiej, Lublin.

Mundry R., Fischer J., 1998. Use of statistical programs for nonparametric tests of small samples often leads to incorrect $P$ values: examples from Animal Behaviour. Animal Behaviour 56: 256-259.

Niedźwiedź T., Cebulak E., Czekierda D., Limanówka D., 1999. Wysokość, natężenie i przestrzenny rozkład opadów atmosferycznych. In: Dorzecze Wisty: monografia powodzi lipiec 1997, J. Grela., H. Słota., J. Zieliński. (eds), Instytut Meteorologii I Gospodarki Wodnej, Warszawa: 23-42.

Nowosad M., 2007. Próba wydzielenia sezonów cyrkulacyjnych nad Europą Środkową. Annales Universitatis Mariae Curie-Skłodowska, LXII: 57-67.

Radomski J., Widawski A, 2011. Influence of circulation types on the $\mathrm{SO}_{2}$ concentration in the Silesian Upland. Prace Geograficzne, Instytut Geografii i Gospodarki Przestrzennej UJ, 126: 53-65.

Radomski J., 2008. Wpływ typów cyrkulacji na stężenie pyłu zawieszonego (PM10) w zimie na Wyżynie Śląskiej. Problemy Ekologii 12: 207-210.

Schubert S., 1994. A weather generator based on the European 'Grosswetterlagen'. Climate Research 4: 191-202.

Siegel S., Castellan N.J., 1988. Nonparametric Statistics for the Behavioural Sciences. McGraw-Hill, New York.

Stach A., 2009. Analiza struktury przestrzennej i czasoprzestrzennej maksymalnych opadów dobowych w Polsce w latach 1956-1980. Wydawnictwo Naukowe UAM, Poznań.

Stachy J., 1999. Polska służba hydrologiczna w 25-leciu 19731997. Gospodarka Wodna 8: 277-283.

StatSoft, 2006. Elektroniczny Podręcznik Statystyki PL, Kraków, WEB: http://www.statsoft.pl/textbook/stathome.html.

Twardosz R., 2007. Diurnal variation of precipitation frequency in the warm half of the year according to circulation types in Kraków, South Poland. Theoretical and Applied Climatology 89: 229-238.

Twardosz R., 2009. Probabilistic model of maximum precipitation depths for Kraków (southern Poland, 1886-2002). Theoretical and Applied Climatology 98: 37-45.

Ustrnul Z., Czekierda D., 2001. Circulation background of the atmospheric precipitation in Central Europe (based on the Polish example). Meteorologische Zeitschrift 10: 103-111.

Ustrnul Z., Wypych A., 2011. Ekstremalne wartości temperatury powietrza w Polsce w świetle różnych typów cyrkulacji. Prace i Studia Geograficzne 47: 87-95. 